\section{Wrap-up Comments}

T.M. (Mike) Apsey, President and CEO, Council of Forest Industries of British Columbia. It is now my task to condense - in a short few minutes - what the members of this distinguished group have told us today about Canada's present and future role in international forest products trade. My comments will reflect what was said today and the papers presented by a number of the speakers. I will also add some of my own comments.

The subject is complex, and in many instances, we are talking about events and relationships that have yet to transpire. But now that all our our panelists have committed themselves, I thought they might be interested in hearing a few other predictions

In 1943, Thomas J. Watson, Chairman of the Board of IBM Corporation said: "I think there is a world market for about five computers.'

In 1962, a record company executive, as he was turning down the BEATLES said: "We don't think they will do anything in this market. Guitar groups are on their way out anyway."

In 1968, the US Magazine Business Week wrote that: "With over fifteen types of foreign cars already on sale here, the Japanese auto industry isn't likely to carve out a big share of the market for itself."

And in 1945, Admiral Leahy of the US Navy said about the atom bomb: "This is the biggest damn fool thing we've ever done. That bomb will never go off ... and I speak as an expert on explosives."

With those reminders of the frailties of human foresight, let me say that I am greatly aided in my task by the fact that we have from today's speakers a common understanding about where Canada currently stands in the world of forest products trade, and where we might be standing tomorrow. This shared understanding arises from a common recognition of the reality of the new international trading environment, and of our ability as a national industry, to cope with it.

The world in which our industry flourished - the one we have left behind - was a simpler place. The few nations favoured with forests and the capital to develop them sold their excess production to nations that lacked - for one reason or another - a sufficient domestic wood supply. There was a rapidly increasing rising demand for what Canadian forest companies produced. We became extremely efficient, high volume producers of basic wood commodities - such as lumber, market pulp and newsprint. We were well adapted to the international trading environment that prevailed between 1960 and 1980. But as we have heard, that environment has changed, and so we are adapting again to meet this new world on its own terms. We have changed before, and we will do so again

Once one of the few exporters of wood, we are now one of many. New producers and new products have entered the international marketplace, at a time when growth in demand has slowed markedly form what it was in the 1970s. Many nations that once imported large quantities of wood are now growing more of their own, often on plantations which can bring a tree from seedling to harvestable age in less than a quarter of the time our trees take to reach maturity. With domestic production replacing imports, new producers in the export market, and slower growth in demand, there is now overcapacity in world forest products trade.

When you add to this situation the effects of currency fluctuations, outbreaks of protectionist sentiments, the development of wood substitutes, and changes in the nature of our forest resource - there can be no doubt that we are traversing a different economic landscape.

As Mr. Kelleher has emphasized in his National Trade
Strategy documents, Canada - more than any other developed nation - lives or dies by foreign trade. And the Canadian forest industry - the largest generator of Canada's export income and provider of one quarter of Canadian manufacturing jobs - is a prime example of the importance of exports to our economy. If there is one clear message that emerged from today's speakers it is that we must secure access to our export markets.

We must remove remaining trade barriers between our industry and its traditional customers, and we must seek to open the door to new markets now denied us by tariff and nontariff restrictions. It should come as no surprise that an industry facing such a challenge is also a strong supporter of initiatives to bring about freer and more secure bilateral trade with the United States, and freer multilateral trade through a new round of GATT discussions.

At the same time, the Canadian forest community also recognizes that our traditional concentration on the production side - while still important - must be matched by more intense and creative efforts to sell what we make and what the customer wants. In this respect, we welcome - and indeed already participate in - cooperative arrangements with government to accelerate our search for new opportunities for forest products in offshore markets.

I believe, that our speakers today are of one mind on the nature of the trading environment we now face, and perhaps more importantly, on how the Canadian forest community must respond.

Mr. Kelleher succintly delivered the federal government's views on the challenges confronting Canada in world markets. The Minister reiterated the Government of Canada's commitment to seek a new bilateral trade agreement with the United States, with the goal of ensuring:

- stable and assured access for our exports;

- reduction of remaining trade obstacles; and

- a better framework of rules for resolving trade disputes.

One need look no further than the ongoing dispute over Canadian lumber exports to the U.S. for proof that better mechanisms for dealing with occasional bilateral tensions are solely needed. As the Minister pointed out, in the U.S. and elsewhere in the world, free trade principles have come under severe strain during the recent period of slower economic growth, shrinking domestic markets and high unemployment. The inevitable response has been the growth of a protectionist backlash the likes of which the world has not seen since the Great Depression. And the worst feature of that backlash in the United States has been the intention, implied or explicit, to unilaterally change internationally accepted trading rules. Hence the debate here at home over the costs and benefits of closer trade relations with the U.S. is not an abstract or academic issue as far as the forest industry is concerned.

Some in Canada have expressed apprehension over what freer trade with our American neighbours might hold for the future of their sectors. That is not the case when it comes to the Canadian lumber industry. In many respects, our lumber industry owes its evolution to the liberalization of trade. Those of us in that industry do not fear free trade because we know free trade. We also know that we Canadians must be talking to the Americans about the nature of Canada-U.S. trade relations in the emerging international trading environment. To a large extent, the future economic health of our industry depends on the outcome of such talks.

We applaud your government's leadership, gentlemen, in seeking the opportunity to formally discuss these and other matters with our most important trading partner. Mr. Kelleher referred to the formation of sectoral advisory groups on international trade. You can bet that this industry will be among those most eager to be part of that process 
And finally, the Minister expressed the government's continuing commitment to cooperative marketing programs and to develop more efective programs in consultation with industry. Again, I know our industry will be pleased to join in this endeavour and build on the good expeience we have already had in this area.

Bill Merken, representing the United States, gave us an American perspective on the issue of freer bilateral trade. $\mathrm{He}$ outlined that there is broad support in the U.S. for the initiative taken by Canada for the talks. He gave us an appreciation of the broad areas of interest to the U.S. - most of which plus others are on Canada's list of interests for the talks.

I feel we are on the threshold of a major piece of history. Handled well, it has every possibility of a win-win situation. We must not permit short-term issues to obstruct improvements in trade between the world's two largest trading partners and we are encouraged with the comments by Mr. Merken.

David Boulter, of the Canadian Forestry Service, offered a penetrating analysis of the shift in world trading patterns, based on the changing balance of comparative advantage between Canadian and Third World producers.

He projected no shortage of industrial roundwood to meet world demand to the year 2000 , and raised the possibility that plantation trees from developing nations would be well able to meet any increase in demand in the early 21 st century. Those projections have serious implications for the Canadian forest community. They underscore the need for reducing our production costs and increasing our marketing efforts, to enable us to compete against offshore producers who can grow their trees faster, and cheaper, than we can.

Mr. Boulter raised the strong possibility that the next century may see an actual reversal of traditional trade flows, with today's importers becoming tomorrow's exporters of forest products. His analysis must prompt us all to examine more closely where Canada's future comparative advantage in forest products trade may be found.

Bernd Koken, of Abitibi-Price, delivered an always timely warning against the dangers of complacently taking our forest income for granted. He noted that Canada has lost major shares in world paper and paperboard trade while the Nordic nations and developing nations increased their market penetration. If, by the year 2000 , we could recover even half the projected market share, Mr. Koken estimated it would create tens of thousands of new Canadian jobs, add significantly to the Gross National Product, and yield huge amounts of revenue to government.

Ray Smith, of MacMillan Bloedel, provided a very clear picture of Canada's current position relative to our competitors, as an exporter of solid wood products in a world not short of what we sell.

Looking to the future, Mr. Smith sees the United States continuing to take the lion's share of Canadian softwood exports, with Pacific Rim countries as the best markets for incremental export growth. He pointedly drew our attention to the area of specialty lumber manufacturing, in which our stock of old growth timber gives us an advantage. But he correctly reminds us that "value added" by itself is no panacea.

Mr. Smith made a strong case for even more sophisticated approaches to marketing, and for innovative research into production, processing and the potential impacts of new reconstituted wood products. Recognizing that future demand for solid wood products is impossible to forecast, he urged that we build on our strengths: trade on the inherent advantages of wood over other materials, and the special qualities of our tree species.

In conclusion, I would like to say that, over the years, I have observed or attended a number of conferences on the economics of the future. But rarely have I seen such unanimity of views on the issues and problems and opportunities facing us as an industry, or as a country.

As I said earlier, I believe we are of one mind about Canada's present trade situation as a forest products exporter, and - more important - about what we must do to ensure ourselves our proper place in a changing international marketplace. The consensus is clear: we are for freer and more secure trade, with all the nations of the world, but especially with our largest trading partner, the United States. We are committed to an intensified export marketing drive, and recognize the need for further cooperation between industry and government in this vital area.

And finally, I believe there is one more message that has been plainly delivered today. And I think I speak for all of us here when I say:

"However difficult this new world may be, however different from the world in which many of us began our careers, we in the Canadian forest community are adapting to it. There is no "sunset"!

One of the underlying themes of this panel and this Congress is the challenge that we face as an industry and a nation. I am reminded of one of President Kennedy's favourite campaign anecdotes. It concerned an Irishman who was walking down a road one day when he came upon a wall in his path. It was quite a formidable wall - high, thick and covered with brambles - and he knew he'd need some strong incentive to get over it. We all know how attached Irish men are to their hats, and after a moment of wondering what to do, he threw his hat over the wall so that we would have to climb over to get it.

Ladies and Gentlemen, this industry threw its hat over the wall some time ago.

Not only is the forest sector important economically to our nation, but it's important psychologically or spiritually as well. The fact that we're hewers of wood - and damn good at it - is part of the Canadian identity. It's something that as a people, we've always been proud of. Perhaps more than any other industry, the Canadian forest industry is seen to be at the core of what is best about this country.

\section{And so it should be.}

We have the natural resources, we have the people, we have the expertise and we have the determination. Provided we can maintain a competitive environment here at home and we have heard excellent and detailed recommendations on how this can be done from the speakers - on market access, exchange rates, transportation policy, energy costs, capital availability, and grants and taxation - and provided we can remove barriers abroad through bilateral and multilateral talks, we will do the job and do it well. 